\title{
Treatment of Shrimp Effluent by Sedimentation and Oyster Filtration Using Crassostrea gigas and $C$. rhizophorae
}

\author{
Roberto Ramos $^{1}$, Luis Vinatea ${ }^{2,3^{*}}$, Walter Seiffert ${ }^{3}$, Elpídio Beltrame ${ }^{3}$, Júlia Santos Silva ${ }^{4}$ \\ and Rejane Helena Ribeiro da Costa ${ }^{4}$ \\ ${ }^{I}$ Departamento de Acuicultura; Facultad de Recursos del Mar; Universidad de Antofagasta; Antofagasta - Chile. \\ ${ }^{2}$ Laboratório de Camarões Marinhos; Departamento de Aqüicultura; Centro de Ciências Agrárias; Universidade \\ Federal de Santa Catarina; 88040-900; Florianópolis - SC - Brasil. ${ }^{3}$ Laboratório de Camarões Marinhos; \\ Universidade Federal de Santa Catarina; Florianópolis - SC - Brasil. ${ }^{4}$ Departamento de Engenharia Sanitária e \\ Ambiental; Universidade Federal de Santa Catarina; Florianópolis - SC - Brasil
}

\begin{abstract}
Efficiency in removing particulate matter from Litopenaeus vannamei shrimp culture effluent was assessed in laboratory scale employing sedimentation and oysters Crassostrea gigas and $C$. rhizophorae filtration processes. Cylindroconical tanks $(100 \mathrm{~L})$ were used in duplicate for sedimentation and 50-L in triplicate for oyster filtration. Fifteen oysters of each species weighing 76-80 $\mathrm{g}$ were stocked in each of the filtration treatment experimental units (biomass of 1065 - $1174 \mathrm{~g}$ oyster per unit). The control treatment was a tank similar to those used in the filtration treatment but with empty oyster shells. Hydraulic retention time of the effluent was of 6 hours in each treatment. First, effluent went through sedimentation, and then the supernatant went through the filtration tanks. Temperature, $\mathrm{pH}$, dissolved oxygen, salinity, turbidity, total suspended solids, total volatile solids, chlorophyll a and BOD $\mathrm{D}_{5}$ were evaluated. During sedimentation and filtration, temperature, $p H$, salinity and dissolved oxygen concentration remained stable. Sedimentation removed 18, 5.6, 27.5, 45.40 and 23.2\% of turbidity, total suspended solids, total volatile solids, chlorophyll $a$ and $\mathrm{BOD}_{5}$, respectively. Chlorophyll a and $\mathrm{BOD}_{5}$ after sedimentation presented significant difference $(P<0.05)$ from the farm crude effluent. For the filtration treatment, $C$. rhizophorae was more efficient removing 62.1, 70.6, 36.1, 100 and 17.2\% of turbidity, total suspended solids, total volatile solids, chlorophyll $a$ and $\mathrm{BOD}_{5}$, respectively, whereas $C$. gigas removed 56.3, 41.2, 27.8, 51.4 and 8.0\% of the same parameters. Statistically comparing $C$. rhizophorae and $C$. gigas performances, there were differences $(P<0.05)$ in removing total suspended solids, total volatile solids and chlorophyll a.
\end{abstract}

Key words: Oysters, filtration, sedimentation, effluent, Litopenaeus vannamei

\section{INTRODUCTION}

Marine shrimp farming is widely practiced in most of Latin-American countries, except in Paraguay and Bolivia due to their inland conditions. In such context, Brazil was the main shrimp producer in 2003 harvesting 90900 tons, surpassing Ecuador and Mexico, the countries that traditionally occupied the first and second places in the production, respectively. Brazil strengthened its position in the Southern hemisphere, occupying the sixth position among the world's farmed shrimp producers (ABCC, 2004). Despite positive expectations, one cannot ignore

\footnotetext{
* Author for correspondence: vinatea@mbox1.ufsc.br
} 
that shrimp farming present significant environmental risks. Uncontrolled growth of shrimp farms in several areas led to environmental destruction, epidemics and decline in the production. Countries such as China, Thailand, Indonesia, Taiwan and Ecuador used to lead the shrimp farm industry but they had its production crashes. Features in common among them were rapid production expansion, poor environmental monitoring and disease outbreaks (Browdy and Hopkins, 1995).

The problems most frequently caused by the shrimp farming are pollution of adjacent water bodies with nutrients and organic matter from the discharge of untreated effluents (Pruder, 1992; Sandifer and Hopkins; 1996; Páez-Osuna et al., 1997), accumulation of suspended matter from the effluents on adjacent estuary or mangrove areas (Nascimento et al., 1998), and disease outbreaks and destruction of mangroves and marshes (PáezOsuna, 2001). Besides nutrients, effluents are also enriched in phytoplankton, bacteria and suspended particulate matter, which concern the society about the sustainability of shrimp farming due to its potential environmental impact (Wang, 1990; Jones et al., 2001). Páez-Osuna et al. (1997) reported that semi-intensive systems were responsible for considerable increases in the levels of suspended solids, chlorophyll $a$ and nutrients. Similar results were observed by Xie et al. (2004) for intensive systems in East China.

According to Primavera (1998), artificial feed is the main responsible for the organic matter in the effluent because only $20 \%$ of the food supplied is assimilated and $80 \%$ remain in the environment as feces or recyclable material. Therefore, an important aspect to be considered is that increased nutrient concentration in the effluent is directly related to the time variation of the shrimp pond during the production cycle (Costanzo et al., 2004). According to Páez-Osuna (2001), the effluent quality is reduced as shrimp grows and culture time extends.

Among the alternatives to minimize the environmental impacts of shrimp farming are effluent treatment in sedimentation tanks (Boyd, 1992; Teichert-Coddington et al., 1999; Nunes, 2002), elimination of water exchange rates (Hopkins, 1995), use of wetlands (Tilley et al., 2002; Souza, 2003), and biological removal of organic and inorganic matters using filtrating mollusks (Shpigel and Neori, 1996; Shpigel et al., 1997; Jara-Jara et al., 1997; Lefevre et al., 2000), macroalgae (Pagand et al., 2000; Nelson et al., 2001) and combination of mollusks, macroalgae and sedimentation (Neori et al., 1998; Jones et al., 2001; Jones et al., 2002; Preston et al., 2003).

In Brazil, studies published on improving shrimp farm effluent water quality are scarce. Use of integrated sedimentation and bivalve's filtration has been little explored and most of information available are abstracts from symposia (Alencar et al., 2003; Gomes et al., 2003; Nascimento et al., 1998; Olivera et al., 2003), and highlight only the use of native oyster Crassostrea rhizophorae as filtrating bivalve.

Considering the need to treat shrimp farm effluents to mitigate environmental impact and also searching for technologies for water reuse, this laboratory scale study used sedimentation and filtration with bivalve mollusks, Crassostrea gigas and $C$. rhizophorae, to compare the efficiency in removing the organic and inorganic matter from shrimp effluent.

\section{MATERIALS AND METHODS}

The study was carried out in October2004. Adult native oyster Crassostrea rhizophorae and Pacific oyster $C$. gigas were provided by the Mariculture Station, Sambaqui (Florianópolis, Santa Catarina). Oysters were originally hatched in the laboratory and grown in suspended long line system. At LCM, oysters were acclimatized for one week in 125-L tanks and fed daily with $30-\mathrm{L}$ of a mixture of two microalgae species Chaetoceros calcitrans and Thalassiosira fluviatilis. Tanks were aerated individually and water was exchanged daily $(60 \%$ of the volume). Before the assay, oysters were externally checked for health status. Those with shells tightly closed and without fouling were chosen and kept without feeding 24 hours prior to tests.

Effluent was collected from Yakult Experimental Shrimp Farm (UFSC), at Barra do Sul (26 32 ' S; $48^{\circ} 39^{\prime}$ W), north littoral of Santa Catarina state. Before 30 days effluent collection ponds had been stocked with juvenile Litopenaeus vannamei shrimp at a density of 15 shrimp $\mathrm{m}^{-2}$, in the semi intensive system. For effluent collection, a regular water exchange was simulated. Five minutes after beginning exchange, water samples were collected in 50-L plastic containers and kept in the dark. In the laboratory, solids were mechanically resuspended. The effluent $(1000 \mathrm{ml})$ was taken to 
analyze physic and chemical variables and nutrients.

For the sedimentation treatment, 100-L dark cylindroconical tanks were used in duplicate. Experimental units were filled with 90-L effluent brought from the Station. The effluent was kept static without aeration. Supernatant was then transferred to the filtration treatment tanks (Fig. 1) and the remaining portion was discharged. Six 50$\mathrm{L}$ cylindroconical dark tanks were used for the filtration treatment. Each tank was filled with $20-\mathrm{L}$ effluent after sedimentation. For each oyster species, experimental units were in triplicate. One tank with empty oyster shells was kept as control for filtration. Filtration tanks were stocked with 15 oysters with mean weight between 76-80 g, totalizing a biomass of 1065 - 1174 g per tank. Oyster species were randomly assigned for each tank. Six hours residence time for the effluent was established for sedimentation and filtration, based on results by Teicheri-Coddington et al. (1999) and our preliminary assays.

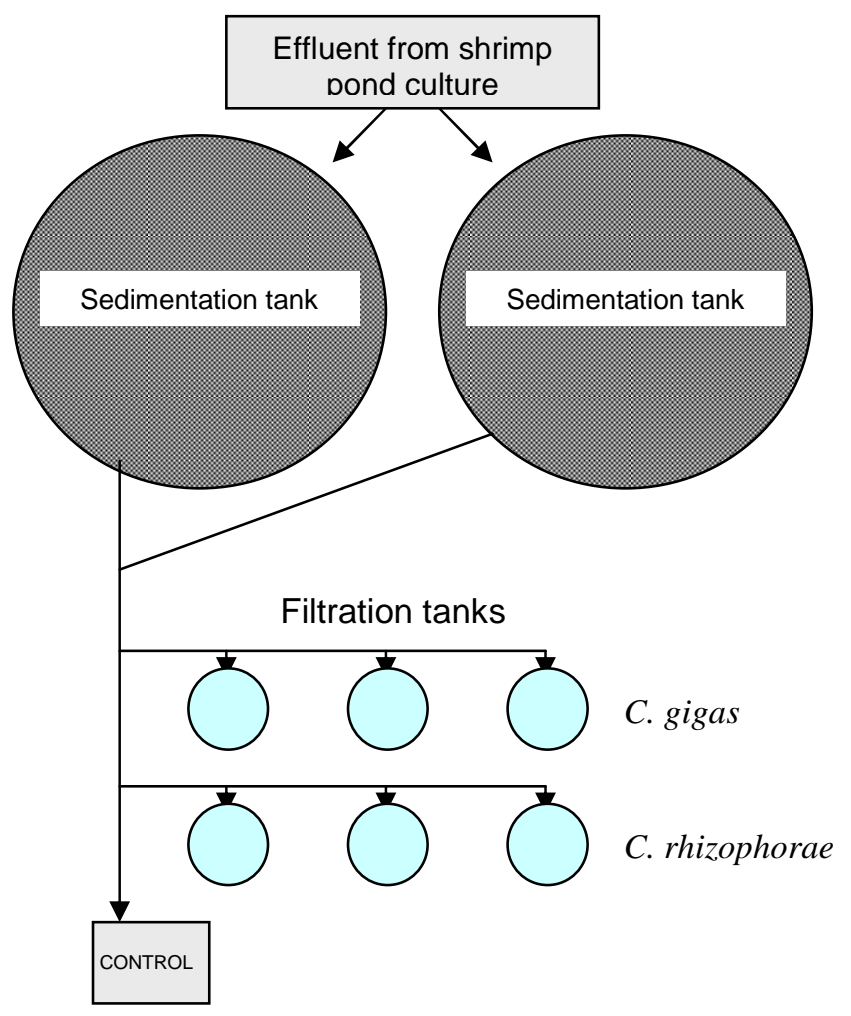

Figure 1 - Schematic drawing of sedimentation and filtration tanks with Crassostrea gigas and $C$. rhizophorae.

In order to determine the removal efficiency for the parameters evaluated in sedimentation and filtration, $1000-\mathrm{mL}$ samples were collected after the 6-hour residence time, following relation proposed by Paniagua and Garcia (2003):

$\mathrm{RE} \%=[($ Effluent Concentration in - Effluent Concentration out)/ Effluent Concentration in] x100

The water quality variables dissolved oxygen concentration $( \pm 0.01)$, temperature $( \pm 0.01)$, salinity $( \pm 0.01)$, and $\mathrm{pH}( \pm 0.01)$ was determined using the multi-parameter device (YSI, MP556 model). Turbidity was measured with turbidimeter (HACH, XR model) expressed in nephelometric turbidity unit (NTU), according to Shpigel et al. (1997). Chlorophyll $a$ was extracted with an ethanol solution and determined by spectrophotometer, following the methodology proposed by Nusch (1980). Water samples for $\mathrm{BOD}_{5}$ determination were incubated for five days (HACH, BOD TRACK model), according to 
APHA (1989). Total suspended solids (TSS) and total volatile solids (TVS) were determined using the method proposed by Clesceri et al. (1989). A known water volume was filtered through a previously dried $\left(110^{\circ} \mathrm{C}\right)$ and weighed fiberglass Whatman $\mathrm{GF} / \mathrm{C}$ filters. Later, filters were dried for $24 \mathrm{~h}$ at $60^{\circ} \mathrm{C}$. TSS was the difference between the filter's final and initial weights. TVS were determined by the loss of weight after combustion of the sample at $500^{\circ} \mathrm{C}$ for $12 \mathrm{~h}$.

Before beginning the experiment, the initial weight of oysters was compared through one-way analysis of variance (ANOVA) to detect significant differences between the means of experimental groups. Mean values and standard deviation were calculated for the two sedimentation tanks and for the three repetitions of each oyster species in the filtration tanks. To determine the possible significant differences $(P<0.05)$ between the treatment means, $t$-test was applied using computer software Statistica 6.0.

\section{RESULTS}

Table 1 shows that water temperature, salinity, dissolved oxygen and $\mathrm{pH}$ did not present noteworthy changes during the experimental phases (sedimentation and filtration), varying between 21.9 to $24.6^{\circ} \mathrm{C}, 21$ to $22 \%$ o, 4.9 to $6.5 \mathrm{mg}$ $\mathrm{L}^{-1}$ and 8.1 to 8.2 , respectively. In general, all the parameters were within the limits considered to be adequate for the species studied here (Poli, 2004), except for temperature, which was out of the range considered to be optimum for the best performance of Crassostrea gigas, a temperate climate and cold water species (Poli, 2004). Salinity also presented some difference when compared to optimum levels for $C$. gigas, which tolerated salinity variations but naturally inhabited marine environments $(34 \%$ \%). On the other hand, dissolved oxygen concentration presented the lowest value $\left(4.9 \mathrm{mg} \mathrm{L}^{-1}\right)$ in the tanks with Pacific oysters. Control tank presented the highest value $\left(6.5 \mathrm{mg} \mathrm{L}^{-1}\right)$ because it did not contain animals.

Turbidity, TSS, TVS and chlorophyll $a$ varied most during the experiment (Tables 2 and 3). During sedimentation, turbidity did not present significant differences $(P>0.05)$, resulting in 23.9 NTU, equivalent to $18.7 \%$ removal after the $6 \mathrm{~h}$ observation. As for filtration, native oysters presented the best value for turbidity removal, removing $62.1 \%$, statistically different $(P<0.05)$ from Pacific oyster's removal of 56.3\%.

Table 1 - Mean values of water quality variables in the crude effluent brought from shrimp pond culture.

\begin{tabular}{ccccc}
\hline Temperature $\left.\mathbf{~}^{\circ} \mathbf{C}\right)$ & $\mathbf{p H}$ & Salinity (\%o) & DO $\left(\mathbf{m g ~ L}^{-1}\right)$ & Turbidity (NTU) \\
\hline $24.6 \pm 0.2$ & $8.2 \pm 0.1$ & $22.0 \pm 0.0$ & $5.3 \pm 0.0$ & $29.4 \pm 0.7$ \\
TSS $\left(\mathrm{g} \mathrm{L}^{-1}\right)$ & $\mathrm{TVS}\left(\mathrm{g} \mathrm{L}^{-1}\right)$ & $\mathrm{Chl} \mathrm{a}\left(\mu \mathrm{g} \mathrm{L}^{-1}\right)$ & $\mathrm{BOD}_{5}\left(\mathrm{mg} \mathrm{L}^{-1}\right)$ & $\mathrm{NH}_{4}\left(\mathrm{mg} \mathrm{L}^{-1}\right)$ \\
$180 \pm 0.0$ & $4.0 \pm 0.0$ & $10.2 \pm 1.4$ & $8.2 \pm 1.5$ & $0.14 \pm 0.0$ \\
\hline
\end{tabular}

(DO) dissolved oxygen concentration; (TSS) total suspended solids; (TVS) total volatile solids; (Chl a) chlorophyll $a$; (BOD) biochemical oxygen demand.

In sedimentation, reduction in chlorophyll $a$ was most remarkable, reducing from 10.2 to $5.6 \mu \mathrm{g} \mathrm{L}{ }^{-1}$, which corresponded to $45.4 \%$ removal. TVS also had an important reduction from 4.0 to $2.9 \mathrm{~g} \mathrm{~L}^{-1}$ (27.5\% removal). This reduction was not followed by TSS, which presented low values, only $5.6 \%$ of the value present in the initial effluent. Another important reduction was in $\mathrm{BOD}_{5}(23.2 \%)$, from 8.2 to $6.3 \mathrm{mg} \mathrm{L}^{-1}$.

In filtration, it was possible to observe the higher performance of the native oyster $C$. rhizophorae for all the evaluated parameters. Performance was remarkable in removing chlorophyll $a$, TSS and turbidity (100, 70.6 and $62.1 \%$, respectively). Native oysters also reached values higher than
Pacific oysters in TVS removal. Native oysters removed $2.3 \mathrm{~g} \mathrm{~L}^{-1}$ (36.1\% removal), whereas Pacific oysters removed $2.6 \mathrm{~g} \quad \mathrm{~L}^{-1} \quad(27.8 \%$ removal). The same trend was observed in chlorophyll $a$ and $\mathrm{BOD}_{5}$ removal, when $C$. gigas presented only 27.8 and $8.0 \%$, respectively. Comparative performance of both species was based on calculation using values from control tank.

Table 3 shows mean values from the replicates both in sedimentation and oyster filtration processes. Figure 2 shows mean values of removal percentage for turbidity, total suspended solids (TSS), total volatile solids (TVS), chlorophyll $a$ $\left(\mathrm{Chl}\right.$ a) and biochemical oxygen demand $\left(\mathrm{BOD}_{5}\right)$ 
for C. gigas and C. rhizophorae filtration, considering the control tank for calculation.

Finally, integrating sedimentation and native oyster filtration processes (best performance) and calculations based on values from crude effluent, it was possible to determine that final removal percentage values were: turbidity $69.3( \pm 2.3)$, TSS 72.2 ( \pm 0.081$)$, TVS $42.5( \pm 1.2)$, chlorophyll a 100 $( \pm 0.0)$ and $\mathrm{BOD}_{5} 12.2( \pm 1.4) \%$.

Table 2 - Mean values of physicochemical parameters in the different phases of the treatment.

\begin{tabular}{|c|c|c|c|c|c|}
\hline Treatment & $\mathbf{T}\left({ }^{\circ} \mathbf{C}\right)$ & Salinity $(\% \circ)$ & DO $\left(\mathrm{mg} \mathrm{L}^{-1}\right)$ & pH & Turbidity (NTU) \\
\hline Crude effluent & $24.6 \pm 0.21$ & $22.0 \pm 0.0$ & $5.3 \pm 0.04$ & $8.2 \pm 0.10$ & $29.4 \pm 0.77^{\mathrm{a}}$ \\
\hline Sedimentation tank & $21.9 \pm 0.63$ & $21.0 \pm 0.0$ & $5.1 \pm 0.007$ & $8.2 \pm 0.04$ & $23.9 \pm 0.56^{\mathrm{a}}$ \\
\hline Control (no oysters) & $21.9 \pm 0.63$ & $22.0 \pm 0.0$ & $6.5 \pm 0.014$ & $8.2 \pm 0.09$ & $23.8 \pm 0.70$ \\
\hline C. gigas & $22.1 \pm 0.14$ & $21.0 \pm 0.0$ & $4.9 \pm 0.04$ & $8.1 \pm 0.16$ & $10.4 \pm 0.77^{b}$ \\
\hline C. rhizophorae & $22.1 \pm 0.14$ & $21.0 \pm 0.0$ & $5.1 \pm 0.21$ & $8.2 \pm 0.05$ & $9.0 \pm 0.49^{\mathrm{a}}$ \\
\hline
\end{tabular}

For Turbidity values, superscript letters indicate significant difference $(P<0.05)$ in the column.

NTU: Nephelometric Turbidity Unit.

Table 3 - Mean values for sedimentation and oyster filtration treatments with six hours hydraulic retention period.

\begin{tabular}{lcccc}
\hline \multicolumn{1}{c}{ Treatments } & $\begin{array}{c}\text { Total suspended } \\
\text { solids }\left(\mathbf{g ~ L}^{-1}\right)\end{array}$ & $\begin{array}{c}\text { Total volatile } \\
\text { solids }\left(\mathbf{g ~ L}^{-1}\right)\end{array}$ & $\begin{array}{c}\text { Chlorophyll a } \\
\left(\boldsymbol{\mu g ~ \mathbf { ~ L } ^ { - 1 }}\right)\end{array}$ & $\begin{array}{c}\text { Biochemical oxygen } \\
\text { demand }\left(\mathbf{m g ~ L}^{-1}\right)\end{array}$ \\
\hline Crude effluent & $0.18 \pm 0.040^{\mathrm{a}}$ & $4.0 \pm 0.003^{\mathrm{b}}$ & $10.2 \pm 1.41^{\mathrm{a}}$ & $8.2 \pm 1.55^{\mathrm{a}}$ \\
Sedimentation & $0.17 \pm 0.003^{\mathrm{a}}$ & $2.9 \pm 0.10^{\mathrm{a}}$ & $5.6 \pm 1.13^{\mathrm{b}}$ & $6.3 \pm 0.84^{\mathrm{b}}$ \\
Control & $0.17 \pm 0.003$ & $3.6 \pm 0.37$ & $3.7 \pm 0.89$ & $8.7 \pm 0.99$ \\
C. gigas & $0.10 \pm 0.006^{\mathrm{a}}$ & $2.6 \pm 0.27^{\mathrm{b}}$ & $1.8 \pm 0.28^{\mathrm{b}}$ & $8.0 \pm 0.49^{\mathrm{a}}$ \\
C. rhizophorae & $0.05 \pm 0.01^{\mathrm{b}}$ & $2.3 \pm 0.49^{\mathrm{a}}$ & $0 \pm 0^{\mathrm{a}}$ & $7.2 \pm 0.85^{\mathrm{a}}$ \\
\hline
\end{tabular}

Superscript letters indicate significant difference $(P<0.05)$ in the column.
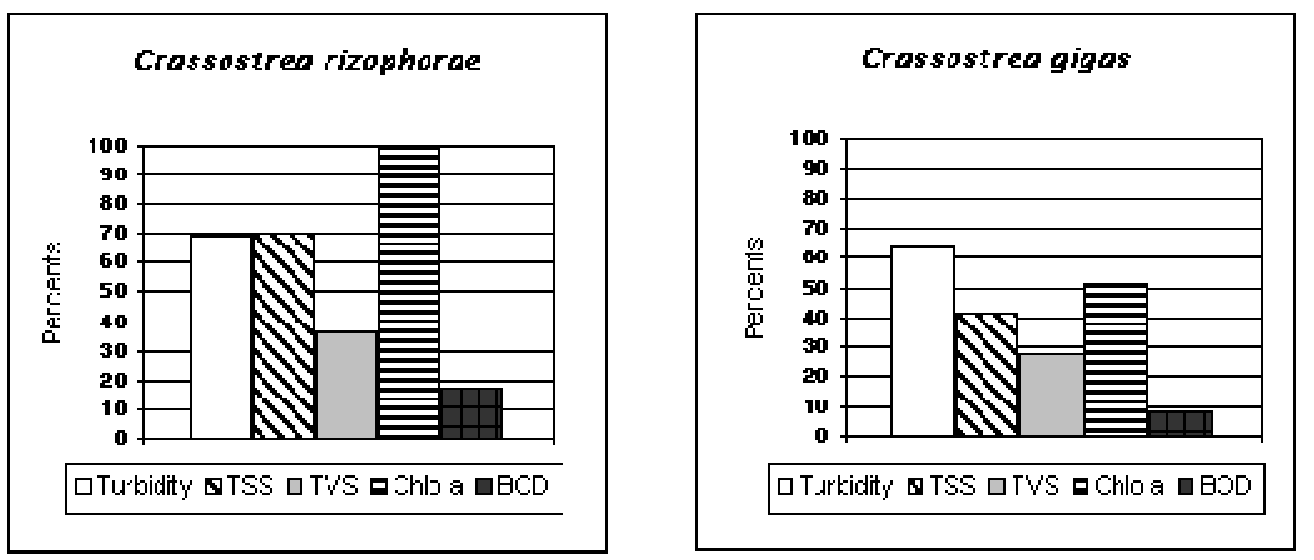

Figure 2 - Mean values for removal percents of the Turbidity, Total Suspended Solids (TSS), Total Volatile Solids (TVS), Chlorophyll a and Biochemistry Oxygen Demand (BOD) for the Crassostrea rizophorae and Crassostrea gigas. 


\section{DISCUSSION}

Results from this study confirmed the previous reports by Teichert-Coddington et al. (1999), Wong and Piedrahita (2000) and Jackson et al. (2003) that sedimentation was effective in reducing the particulate matter from shrimp culture effluent. TSS $\left(0.18 \mathrm{mg} \mathrm{L}^{-1}\right)$, TVS $\left(4.0 \mathrm{~g} \mathrm{~L}^{-}\right.$ $\left.{ }^{1}\right)$, chlorophyll $a\left(10.21 \mu \mathrm{g} \mathrm{L}^{-1}\right)$ and $\mathrm{BOD}_{5}(8.2 \mathrm{mg}$ $\left.\mathrm{L}^{-1}\right)$, registered in the crude effluent from the station were below than the results presented by Teichert-Coddington et al. (1999) and Jones et al. (2001). This indicates an effluent of better quality and the result was directly related to the moment in the culture period, i. e., beginning, middle or end of growth phase, as reported by Costanzo et al. (2004) and Páez-Osuna (2001). Other factors that determine the physicochemical characteristics of the effluent are quality of food supplied, shrimp digestion ability and pond capacity to recycle nutrients.

As previously mentioned, culture stage is an aspect that should be considered in the efficient removal of suspended solids because at the shrimp final growth phase the effluent has a higher load of nutrients than at the beginning of the cycle (Constanzo et al., 2004). In the present study, the effluent used corresponded to 30 days of culture, a considerably new effluent, because shrimp was harvested after 90 days of culture. Although this point has not been evaluated in this study, physic, chemical and biological characteristics of the effluent could explain the difference seen in the efficiency in removing the suspended matter.

Despite differences in methodology, results presented by Teichert-Coddington et al. (1999), with $6 \mathrm{~h}$ hydraulic retention of the effluent during sedimentation, were better than those found in this study as regards particulate matter removal. In their study total solids removal was $88.2 \%$, total volatile solids $70.9 \%$ and $\mathrm{BOD}_{5} 63.1 \%$, and in this study the values were of 5.6, 27.5 and $23.2 \%$, respectively. Hence different results could be explained by the fact that Teichert-Coddington et al. (1999) evaluated the last $20 \mathrm{~cm}$ of pond water in the sedimentation process.

Accordingly, results obtained by Jones et al. (2001), with $24 \mathrm{~h}$ residence of the effluent for sedimentation, were higher than those found in the present study. Preston et al. (2003) obtained a removal of $60 \%$ of total suspended solids with 2 to 3 days of effluent residence. Effluent residence time has an important effect on the efficiency in removing the particulate matter, as demonstrated by Chien and Liao (1995) and Páez-Osuna (2001). Another important factor influencing sedimentation efficiency is salinity. Day et al. (1989) stated that sedimentation rate of the suspended matter was faster in salt water than in freshwater due to a strong ionic association of dissolved salts, which neutralized negative charges of suspended particles (clay, colloidal humic acids among others). This was opposite to freshwater, where negative charges should be repelled keeping particles in suspension. The present study was carried out in salinity between 21-22\%o. Although this variable was not evaluated, salinity could have influenced sedimentation efficiency. Jackson et al. (2003) showed that several factors could influence efficient removal of suspended particles, further to those just mentioned, such as shape and handling of the sedimentation tank, effluent composition and biological processes.

Use of bivalve mollusks as biofilters has been recommended by several authors (Shpigel and Neori, 1996; Neori et al., 1998; Jones et al., 2001; Jones et al., 2002; Nunes, 2002). In this study, suspended matter removal efficiency was tested using the Pacific oyster Crassostrea gigas and the native oyster Crassostrea rhizophorae at $22^{\circ} \mathrm{C}$, salinity of $21 \%$ and $\mathrm{pH}$ of 8.1 . It was observed that the Pacific oyster presented lower filtration performance than the native oyster for all the parameters evaluated.

This result could be explained by salinity, since Pacific oyster used in the study were hatched in salt water and the adults came from suspended system in the sea at $35 \%$. Such salinity condition is different from those of the shrimp culture effluent, with a much lower salinity of $21 \%$. Although the oysters were acclimatized for one week in the experimental salinity, further to their tolerance to daily variations from zero to $35 \%$ o (Poli et al., 2004), difference between salinity in the sea and in the study (22\%o) was significant (13 $\%$ o). However, similarly to Pacific oysters, native oysters originated from wild brood stock, which lived and grew where wide salinity variation occurred, from zero during low tides in rainy seasons to $40 \%$ during high tides in dry seasons. Therefore, salinity in the natural habitat ranges between 7.2 to $28.8 \%$ o. It is important to highlight that in negative conditions of salinity changes occur in the physiology of organisms, making oysters to shut their shells and do not feed (Kinne, 
1972), which may have happened to Pacific oysters.

On the other hand, low $C$. gigas performance could be possibly explained by the temperature of the experiment, $4^{\circ} \mathrm{C}$ higher than the temperature in which they were cultured $\left(18^{\circ} \mathrm{C}\right)$. According to Poli et al. (2004) that specie is typical of cold waters and it is expected that they develop better in environments similar to their natural habitat. In Santa Catarina, such low water temperatures happen in winter, when minimum can reach $14.5^{\circ} \mathrm{C}$. In summer, oysters interrupt growth due to temperature that goes as high as $28^{\circ} \mathrm{C}$. It is widely documented that water temperature is as a critical factor in poekilothermic animals, especially bivalve mollusks. Shpigel and Blaylock (1991) reported that maximum growth and condition index for $C$. gigas occurred during winter and that temperature of about $27^{\circ} \mathrm{C}$ reduce the growth. This biological characteristic can eventually be limiting for associated or individual cultures, using shrimp effluent, since $L$. vannamei presents its best growth potential at $28^{\circ} \mathrm{C}$, temperature that is negative for the development of Pacific oysters.

Another important aspect that should be considered is the water ammonia concentration, which can reduce $C$. virginica filtration down to $50 \%$, from concentrations of $140 \mathrm{mg} \mathrm{NH}-\mathrm{N} \mathrm{L}^{-1}$, and tolerance limit being between 110 and $880 \mathrm{mg}$ $\mathrm{L}^{-1}$ (Epifanio and Sma, 1975). Boyd et al. (1989) found that sedimentation was not an effective method to remove ammonia.

During filtration, oysters select particles according to size, weight and chemical composition, preferring organic matter and rejecting inorganic matter (Jones et al., 2002). This explains the high filtration rates of TVS and chlorophyll $a$ in both species. Jones et al. (2002) reported that oysters removed high concentrations of phytoplankton, bacteria and other solids suspended in the water column. Analyzing final numbers after integrating the process of sedimentation and native oyster filtration, the removal efficiency was even better for TSS, TVS and chlorophyll $a$, with values of $72.2,42.5$ and $100 \%$, respectively.

According to the experimental conditions, it was possible to conclude that the native oysters Crassostrea rhizophorae presented higher filtration efficiency than Pacific oyster $C$. gigas, consequently higher capability to remove total suspended solids, volatile solids and chlorophyll $a$. Furthermore, the combination of sedimentation and filtration processes increased the removal of particulate matter, improving the water quality of L. vannamei shrimp culture effluents.

\section{ACKNOWLEDGEMENTS}

The authors are grateful to CNPq CT-Agro (Project 504277/2003-0) and MECESUP-CHILE ANT 0106 for the financial support; Laboratório de Camarões Marinhos (LCM - UFSC) and Laboratório Integrado de Meio Ambiente (LIMA UFSC) for providing their facilities; Dr. Jaime Ferreira, from Laboratório de Moluscos Marinhos (LMM - UFSC) for providing the oysters; Rodrigo Schveitzer and Jairo de Souza, technicians at LCM and Yakult Experimental Shrimp Farm (UFSC), respectively, for collecting the effluent.

\section{RESUMO}

Em escala laboratorial, foi comparada a eficiência de remoção de material particulado presente no efluente do cultivo de camarão branco Litopenaeus vannamei, mediante o processo de sedimentação e filtração com ostra nativa Crassostrea rhizophorae e com ostra do pacifico Crassostrea gigas. No processo de sedimentação foram empregados tanques cilindro cônico, em duplicata, de cor preta com $100 \mathrm{~L}$ de capacidade total. Para o processo de filtração foram empregados tanques cilindro cônicos, em triplicata, de cor preta de $50 \mathrm{~L}$ de volume total. No tratamento de filtração cada unidade experimental foi estocada com 15 indivíduos de ostras de ambas as espécies, com peso médio entre $76-80 \mathrm{~g}$, mantendo uma biomassa entre 1.065 e $1.174 \mathrm{~g}$ ostra por unidade. Também foi empregado um tanque com as mesmas características ao de filtração, como controle, contendo apenas conchas de moluscos sem animal. O tempo de retenção hidráulica do efluente, em cada tratamento, foi de 6 horas, passando primeiro pelo processo de sedimentação e posteriormente o sobrenadante foi transferido para a filtração. As variáveis avaliadas no estudo foram $\mathrm{pH}$, temperatura, oxigênio dissolvido, salinidade, turbidez, sólidos suspensos totais, sólidos voláteis totais, clorofila $a$ e $\mathrm{DBO}_{5}$. No processo de sedimentação e de filtração, as variáveis temperatura, $\mathrm{pH}$, salinidades e oxigênio dissolvido se mantiveram estáveis. $\mathrm{O}$ tratamento de sedimentação conseguiu uma remoção de 
$18,7 \% ; 5,6 \% ; 27,5 \% ; 45,4 \%$ e $23,2 \%$, para a turbidez, sólidos suspensos totais, sólidos voláteis totais, clorofila $a$ e $\mathrm{DBO}_{5}$, respectivamente, sendo que a clorofila $a$ e a $\mathrm{DBO}_{5}$ foram as variáveis que no processo de sedimentação apresentaram diferenças estatísticas $(\mathrm{P}<0,05)$ em relação ao efluente bruto da fazenda. No processo de filtração, a ostra $C$. rizophorae resultou ser mais eficiente na remoção do material particulado do que a ostra $C$. gigas, com valores de $62,1 \%$; $70,6 \% ; 36,1 \% ; 100 \%$ e $17,2 \%$ para as variáveis turbidez, sólidos suspensos totais, sólidos voláteis totais, clorofila $a$ e $\mathrm{DBO}_{5}$, respectivamente. No mesmo processo, $C$. gigas obteve valores de $56,3 \% ; 41,2 \% ; 27,8 \% ; 51,4 \%$ e $8,0 \%$ para as essas variáveis. Quando comparados estatisticamente, os desempenhos da $C$. rizophorae e $C$. gigas, no processo de filtração, observam-se diferenças significativas $(\mathrm{P}<0,05)$ na remoção de sólidos suspensos totais, sólidos voláteis totais e clorofila a. De acordo com os resultados obtidos, nas condições experimentais do teste, pode-se concluir que a ostra nativa apresenta um melhor desempenho que a ostra do pacifico no referente à eficiência de remoção de todos as variáveis avaliadas.

\section{REFERENCES}

ABCC (2004), Carcinicultura Brasileira: o censo de 2003. Panorama da Aqüicultura. Março - Abril 2004.

Alencar, J., Horta, P., Emoto, S., Dutra, F., Weiss, L., Bouzon, Z. (2003), Evaluation of Ulva lactuca (Ulvales, Chlorophyta) growth in different salinities: an alternative for the treatment of carciniculture effluents in the South of Brazil. In- Book of Abstracts, v. 2, World Aquaculture Meeting, May 19-23, 2003. Salvador, Brazil.

APHA (1989), Standard Methods for the Examination of Water and Wastewater. American Public Health Association. Springfield, Byrd Press, 15 th ed.

Boyd, C. (1992), Shrimp pond bottom soil and sediment management. In- Wyban, J. (ed) World Aquaculture Society '92. Proceedings of the Special Session on Shrimp Farming. Baton Rouge: World Aquaculture Society, 1992. pp. 166-181.

Boyd, C., Gross, A., Rowan, M. (1989), Laboratory study of sedimentation for improving quality of pond effluents. J. Appl. Aquaculture, 8, 39 - 48.

Browdy, C., Hopkins, J. (1995), Swimming through troubled water. In- Proceeding of the Special Session on Shrimp Farming. San Diego; The world Aquaculture Society.
Day, J., Hall, C., Kemp, W., Yanez-Arancibia, A. (1989), Estuarine Ecology. Wiley, New York.

Chien, Y., Liao, I. (1995), Integrated approach to shrimp grow out system design. In- Browdy, C.L., Hopkins, J.S. (Eds.), Swimming Through Troubled Water. Proceeding of the Special Session on Shrimp Farming. World Aquaculture Society, Baton Rouge, pp. $167-179$.

Clesceri, L., Greenberg, A., Trussel, R. (1989), Standard Methods for Examination of Water and Wasterwater. American Public Health Association, New York.

Costanzo, S., O’Donohue, M., Dennison, W. (2004), Assessing the influence and distribution of shrimp pond effluent in a tidal mangrove creek in north-east Australia. Mar. Pollut. Bull. 48, 514-525.

Epifanio, C., Sma, R. (1975), Toxicity of ammonia, nitrite ion, nitrate ion and orthophosphate to Mercenaria mercenaria and Crassostrea virginica. Marine Biology, 33, 246 - 249.

Gomes, I., Lacerda, E., Leite, A., Olivera, A. (2003), Effluent treatment of Litopenaeus vannamei (Boone, 1831) in laboratory, using three stages, sedimentation, oyster filtration and macroalgae absorption. In- Book of Abstracts, v. 2, World Aquaculture Meeting, Salvador, Brazil.

Hopkins, J. (1995), A review of water management regimes, which abate the environmental impacts of shrimp farming. In- Browdy, C. L. and J. S. Hopkins (eds). Proceedings of the Special Session on Shrimp Farming. Baton Rouge, World Aquaculture Society, pp.157-166.

Jackson, C., Preston. N., Buford, M., Thompson, P. (2003), Managing the development of sustainable shrimp farming in Australia: The role of sedimentation ponds in treatment of farm discharge water. Aquaculture, 226, 23 - 34.

Jara-Jara, R., Pazos, A., Abad, M., Garcia-Martin, L., Sanchez, J. (1997), Growth of clam seed (Ruditapes decussatus) reared in the wasterwater effluent from a fish in Galicia (N.W.Spain). Aquaculture, 158 (3/4), 247-262.

Jones, A., Dennison, W., Preston, N. (2001), Integrated treatment of shrimp effluent by sedimentation, oyster filtration and macroalgal absorption: a laboratory scale study. Aquaculture, 193, $155-178$.

Jones, A., Preston, P., Dennison, W. (2002), The efficiency and condition of oyster and macroalgae used as biological filters of shrimp pond effluent. Aquaculture Research, 33, 1 - 19.

Kinne, O. (1972), Environmental factors. In- Kinne, O. (Ed.) Marine Ecology.

Lefevre, S., Barillé, L., Claire, M. (2000), Pacific oyster (Crassostrea gigas) feeding responses to a fish-farm effluent. Aquaculture, 187 (1/2), 185-198.

Nascimento, I., Mangabeira, F., Evangelista, A., Santos, A., Pereira, S., Silvany, A., Carvalhal, G. (1998), Cultivo integrado de camarões e ostras: a busca de 
uma tecnologia limpa para o desenvolvimento sustentado. In- Anais de Aqüicultura Brasil'98 Desenvolvimento com Sustentabilidade. Recife-PE ABRAQ, v.2 , pp. $503-514$.

Nelson, S., Glenn, E., Conn, J., Moore, D., Walsh, T., Akutagawa, M. (2001), Cultivation of Gracilaria parvispora (Rhodophyta) in shrimp-farm effluent ditches and floating cages in Hawaii: a two-phase polyculture system. Aquaculture, 193 (3/4), 239-248.

Neori, A., Ragg, N., Shpigel, M. (1998), The integrated culture of seaweed, abalone, fish and clams in modular intensive land-based systems: II. Performance and nitrogen portioning within an abalone (Haliotis tuberculata) and macroalgae culture system. Aquacultural Engineering, 17, 215 239.

Nunes, A. (2002), Tratamento de efluentes e recirculação de água na engorda de camarão marinho. Panorama da Aqüicultura, 71, 27 - 39.

Nush, E. (1980). Comparison of different methods for chlorophyll and phaeopigment determination. Arch. Hydrobiol.Beith. 14, 14-36.

Olivera, A., Guimarães, E., Alves, G., Guimarães, I. (2003), Shrimp farming effluent treatment using the "Native Oyster" Crassostrea rhizophorae (Guilding, 1828 ) in rio Formoso community-PE, Brazil. InBook of Abstracts, v. 2, World Aquaculture Meeting, May 19-23, 2003 Salvador, Brazil.

Páez-Osuna, F., Guerrero-Galvan, S., Ruiz-Fernandez, A., Espinoza-Angulo, R. (1997), Fluxes and mass balances of nutrients in a semi-intensive shrimp farm in north-western, Mexico. Mar. Pollut. Bull., 34, 290 $-297$.

Páez-Osuna, F. (2001), The environmental impact of shrimp aquaculture: a global perspective. Environmental Pollution, 112, 229-231.

Pagand, P.; Blancheton, J. Lemoalle, J.; Casellas. C. (2000), Low density fish farm including unit containing Ulva lactuca or Gracilaria verrucosa. Aquaculture Research, 31 (1), 729.

Paniagua-Michel, J., Garcia, O. (2003), Ex-situ bioremediation of shrimp culture effluent using constructed microbial mats. Aquacultural Engineering, 28, 131 - 139

Poli, C. (2004), Cultivo de ostras do Pacífico Crassostrea gigas. In- Poli, C. R., Poli, A. T. B., Andreatta, E., Beltrame, E. (org.), Aqüicultura: Experiências Brasileiras. Multitarefa, Florianópolis, pp. $251-266$.

Preston, N., Christopher, J., Buford, M. (2003), Recent advances towards minimizing and managing waste nutrients from intensive shrimp farms in Australia.
In- Book of Abstracts, v. 2, World Aquaculture Meeting, May 19-23, 2003 Salvador, Brazil.

Primavera, J. (1998), Tropical shrimp farming its sustainability. In- Tropical Mariculture. Academic Press., London. pp. 257-289.

Pruder, G. (1992), Marine Shrimp pond effluent: Characterization and environmental impact. InWyban, J. (ed.), Proceedings of the Special Session on Shrimp Farming. Baton Rouge: World Aquaculture Society, pp. $187-1190$.

Sandifer, P., Hopkins, J. (1996), Conceptual design of a sustainable pond-based shrimp culture system. Aquacultural Engineering, 15, 41 - 52.

Shpigel, M., Blaylock, R. (1991), The oyster Crassostrea gigas, as a biological filter for a marine fish aquaculture pond. Aquaculture, 92, 187- 197.

Shpigel, M., Neori, A. (1996), The integrated culture of seaweed, abalone, fish and clams in modular intensive land-based systems: I. Proportions of size and projected revenues. Aquacultural Engineering, 15, 313 - 326.

Shpigel, M., Gasith, A., Kimmel, E. (1997), A biomechanical filter for treating fish-pond effluents. Aquaculture, 152, 103-117.

Souza, T. (2003), Tratamento de efluentes de carcinicultura por dois wetlands artificiais pilotos, com e sem Spartina alterniflora. Perspectivas de aplicação. (MSc dissertation). Florianópolis, Universidade Federal de Santa Catarina.

Teichert-Coddington, D., Rouse, D., Potts, A., Boyd, C. (1999), Treatment of harvest discharge form intensive shrimp pond by settling. Aquacultural Engineering, 19, 147 - 161 .

Tilley, D., Badrinarayanan, H., Rosati, R., Son, J. (2002), Constructed wetlands as recirculation filters in large-scale shrimp aquaculture. Aquacultural Engineering, 26, 81-109.

Wang, J. (1990), Managing shrimp pond water to reduce discharge problems. Aquacultural Engineering, 9, 61-71

Wong, B., Piedrahita, R. (2000), Settling velocity characterization of aquacultural solids. Aquacultural Engineering, 21, 233 - 246.

Xie B., Zhuhong, D., Xiaorong, W. (2004), Impact of the intensive shrimp farming on the water quality of the adjacent coastal creek from Easter China. Mar. Pollut. Bull., 48, 543-553. 